\title{
The Phenomenon of WhatsApp Group and The Formation of a New Political Identity
}

\author{
Syahrir Karim ${ }^{1}$ \\ \{sahrirka@gmail.com ${ }^{1}$ \} \\ Islamic State University of Alauddin, Jln. H.M. Yasin Limpo No. 36, Gowa, Indonesia ${ }^{1}$
}

\begin{abstract}
This paper examines the widespread phenomenon of the use of WhatsApp groups and their relevance in forming a new political identity. Identity of political populism that has been rife all this time could be due to the massive role of the spread and ideological movements in WhatsApp groups. This study uses a phenomenological approach with the type of qualitative research. The findings in this study include that WhatsApp groups are considered as the most strategic media in spreading certain ideologies. The pattern used is like, creating a group and then inviting people to join the group. In the group there are administrators and political and ideological patrons who are usually heard and influential. This method is considered as a substitute for conventional models such as making halaqah face to face or cadre models of members that have been around. Compared to other social media, such as Facebook, Twitter, Instagram, Line, etc., WhatsApp is more familiar in all circles than other social media. WhatsApp is considered a very strategic place in spreading certain ideological messages, including influencing the character and mindset, especially members of the group. This follows a trend of spreading hoax, political interests and certain ideologies that are increasingly mushrooming in text messaging applications
\end{abstract}

Keywords: Political Identity; Post-Truth; Social Media and WhatsApp Group.

\section{Introduction}

Indonesia, with complex democracies, diverse populations, and the largest Muslim population in the world has become a challenge. The biggest problem that is happening now is the rise of identity political populism which might determine Indonesia's future. Both in the 2014 Presidential Election and the current elections, the problem of dividing race, ethnicity, and religion, has been fully exploited by activists. The effect of this strategy has been strengthened by the use of hoax that has spread rapidly on social media. A globalized posttruth atmosphere -where emotional appeal trumps rational debate- blurs public perceptions and the ability of voters to discuss the issues well. The behavior and relationships of online network members that influence choice and personal actions show that WhatsApp groups that thrive in Indonesia are forms of the online networks that have the potential to become future identity political movements.

This paper examines how the WhatsApp Group phenomenon raises new political identities in society. The rise of the Islamic movement or other movements lately have raised the question whether this movement purely due to the awareness of rationality or irrational.[1] Sees that the research on online religious communities also considers how Web 2.0 technology provides new possibilities for online community creation and challenges offline religious communities. 
He also revealed that religious blogging studies shows that individuals can use their online activities to consciously reject traditional forms of community and instead of choosing to build religious identities and networks that enable them to experiment with new ways of online religious interaction.[2] This study shows that the phenomenon of hoax and WhatsApp Group also contributed to the emergence of new political identities among the society. The rise of WhatsApp Group and hoax news has formed its own political identity in society with its various typologies. The phenomenon of WhatsApp Group for example is formed with the identity of affiliation, profession, interests and group identity, etc. This tendency for discussions and issues in the WhatsApp Group sometimes creates the impressions of political patrons or figures who are considered influential and respected. This tendency gives space to the emergence of framing issues and the indoctrination process for the group members. Finally, this political identity has given a tendency to political polarization and personal politics. So that, in the end the irrational and even radical politics emerged. The tendency of issues disseminated and repeated will be real truth (post-truth) and has psychological and thoughtful effects. This is why the government through the police has overseen the WhatsApp groups in Indonesia.

The above phenomenon is a serious problem that must be studied more deeply. How populism of political identity in Indonesia is increasing especially in every political contestation. So that this research can give an idea of the phenomenon of how social media is currently influential in shaping the mindset of society, especially the dissemination of certain understandings or ideologies.

\section{Research Method}

This study uses the theory of post-truth and political identity with using the phenomenology approach. This research was conducted with qualitative methods. One reason is that the symptoms under study are more likely dynamic social phenomenon. In addition, the subject matter in this research is related to the role of politics ethnic. The data cited in this study were analyzed descriptively and analytically, which not only provided a description of the phenomenon, but also explained and analyzed it so that it could assess in full, detailed, and mandatory the phenomena obtained from the field. This research will take the example of some forms of hoaxes and WhatsApp groups to use as important data including interviews. Why only WhatsApp group as the focus of study not other social media such as Facebook, Twitter, Instagram, etc., because the use of WhatsApp is more closed and more familiar in almost all circles, both young and old people.

\section{Result and Discussion}

In the current era of modern democracy, the industrial phenomenon of using political consultants, political buzzers, in campaigns in the digital world or social media have enlarged political identity. This buzzer pattern by using several accounts in social media, identity politics content is produced and reproduced in number. Political identity itself is theoretically first explained by L.A Kauffman[3] who looked at the nature of identity politics when tracing its origins in the Student Nonviolent coordinating committee (SNCC), a civil rights movement 
in the United States in the early 1960s. Although actually it's still unclear who was the founder of this theory. However, in substance this identity politics is often associated with the interests of members of a social group who feel blackmailed and marginalized by the dominance of large currents in a nation or state.[4] In the Indonesian context, identity politics is actually more inclined to the argument of social justice, not for religious reasons only. In this perspective, the Muslim Movement in Indonesia in recent years is not purely due to religious factors alone but there is a factor of unfair treatment. There are several groups, schools of thought or ideologically strong schools who feel they have been treated unfairly by the state such as Hizbut Tahrir Indonesia (HTI), the criminalization of the clerics and others.

The increasing political identity in national and local political discourse lately is inseparable from the success of the main actors in this Movement in campaigning agenda. The pattern of campaigns using social media is very effective, including creating WhatsApp groups. In WhatsApp groups a kind of indoctrination occurs, especially building awareness of shared identity through certain ideologies. At this point, what is emphasized is the narrative of emotionality rather than the narrative of rationality. With this model of campaign and indoctrination process, it has succeeded in influencing the emotions of the people who have finally reached the point of post-truth symptoms that have occurred so far. The term that relates to post-truth is truthiness, which is seemed true, though not true at all.[5] The term post-truth is more concerned with emotional feelings than objective data of facts. So the facts in this case are considered not very influential in shaping public opinion compared to personal emotions and beliefs. Along with that, social media especially the existence of WhatsApp groups is the most effective media in influencing one's personal emotions and beliefs. This phenomenon becomes increasingly serious when the credibility of the mainstream media is always undermined by the interests of elites and owners, forcing people to look for alternative information even though the information is unclear or not objective.

This study finds that WhatsApp Group media is one of the most significant ways to form new groups and even new social identities. The existence of WhatsApp Group is used as a forum for the process of new understanding or ideology indoctrination for all group members. Some cases show how the process took place, such as systematic and massive recruitment, patrons or influential people. The existence of group members can be issued by the admin group when there is a mismatch of perception and understanding. The implication of this phenomenon is that social media has become a very efficient place in spreading new ideologies including by spreading hoaxes. This not only creates divisions within the community and family, but also threatens national solidarity.[6] In an election where identity politics is a game and hoax card is a campaign strategy, not only social solidarity, but also the country's democratic foundation at stake. The media has had a profound influence on the formation of thought patterns and the spread of ideology.[7] gave the view that one of the political strategies that are widely used in influencing voter behavior is the use of media. In some cases it was found that social media in this case WhatsApp group is the most strategic place in spreading certain ideologies. Creating a WhatsApp group and then inviting people to join the group is a new strategy that was previously carried out by conventional ideology, conventional methods such as creating an organization, cadre in a closed room, halaqah, and others with face to face model.

The pattern of political movements that require social media has been successful. Political actors no longer try in their ideology and political interests. Social media through WhatsApp groups issued very success in building political movements and has been proven in recent years in political contestation in Indonesia. For example, the impression of Islamic politics used by a pair of certain candidate pairs in the presidential election, regional elections 
as well as governor elections with full support of the alliance of ulama in the ijtima Ulama forum, the 212-alumni movement led by Islamic Defenders Front (FPI), The National Movement of The Ulama Fatwa Defenders (GNPFU) and other political Islamic movements. If the above assumption is not proven, it means winning one of the candidate pairs in political contestation caused by other political aspirations, such as identity political factors, unequal distribution of wealth, unfair natural resources, infrastructure development that has not really benefited for Public. Therefore, research has answered that political dynamics and their relationship with the phenomenon of the political Islam movement originated from the strengthening of identity politics that originated from social media.

Populism of political Identity in recent years has changed the political character of society from rational to emotional or irrational. This research offers a new perspective about social media, in this case that the existence of WhatsApp groups is a new pattern in building social movements. There are three concepts of social movement theory that are very important, namely political opportunity structure, framing, and mobilizing structure. As part of social movement theory, framing is a knife of analysis that is often used in looking at patterns of movement activism and ideology. Framing is a process in which social movement actors create and roll out discourse that can reverberate among those who are targeted mobilization as stated. Framing can be formulated as the art of communicating messages to persuade the masses and gain support and participation. For this reason, various issues and symbols are chosen and contextualized to achieve "frame resonance", that is enough responses that will change potential mobilization into actual mobilization.[8] The echo of the framework of collective action becomes the basis for social movement actors to create their collective identity, an interactive orientation of action and the opportunities and obstacles in which the action takes place. A strong sense of collective identity determines the decisions taken by the actors and the way they adapt their activities to changing situations.[9] From some of the social movement characters, all of these characters are in the WhatsApp groups. In the WhatsApp group there is a framing of issues, the process of indoctrination arises with certain political interests amid political moments, and in the WhatsApp group is also inhabited by political actors as a resource power.

\section{Conclusion}

In order to prevent the enhancement of negative politics identity, it needs an ideological basis and strong idealism from everyone. The importance of right understanding of the use of social media is important for education to all levels of society. Identity politics that are disseminated through various online media and social media have become a place for prominent public and political figures or figures as well as delivering truth claims. Every speech from a figure is posted on the timeline and shared by users to friends and groups on various social media such as WhatsApp, and others. The community believes that what is conveyed by the character is a truth. People who immediately believe and no longer think whether the information submitted is true or not, but the belief in the figure has denied the objective truth that they should have. Truth no longer lies in the validity of information but its belief in a figure. The impact of media is not limited to the behavioral consequences of media messages, but has led to a more personal impact on emotions. This is among the causes of the emergence of hate speeches and hoax news on various social media. When truth is no longer 
based on objective factors but someone's beliefs and feelings towards a figure, then there will be coercion to others who are believed to be the truth.

The above phenomenon concludes that political movements are no longer conventional but are also beginning into the part of digital arena. The pattern of this movement has proven successful in recent years, especially seen in every democratic contestation in Indonesia. Political identity as long as it is seen is the effect of the massive campaign through social media. Social media has become a very strategic tool in spreading issues, ideologies, each of which can be consumed by its users. So that, it has implications in changing mindsets to the level of public emotional is higher than the facts. Society is no longer objective in assessing things. It was at this point that the term post-truth emerged, that the present era is the era of post-truth. That is an era where people prioritize their emotions over their rationality. Therefore, when rationality is no longer put forward then what emerges is personal politics even communal politics which will results in a new political identity.

\section{References}

[1] Lovheim, M. : Identity On Digital Religion Understanding Religius Practice in New Media Worlds. (London and New York: Routledge) (2013)

[2] Teusner, P. : Emerging Church Bloggers in Australia Prophets, Priests and Rulers in God's Virtual World. (Melbourne: RMIT University) (2010)

[3] Kauffman, L. : The Anti-Politics of Identity, Socialist Review. Vol. 20. (2012)

[4] Ma'arif, A. S. : Politik Identitas dan Masa Depan Pluralisme Kita. (Jakarta: Yayasan Abad Demokrasi) (2012)

[5] Syuhada, K. : Etika Media di Era Post-Truth. J. Kumunikasi Indones., Vol. 5. pp. 75-79 (2017)

[6] Sosiawan, E. and Wibowo, R. : Representasi Politik Identitas dalam Kampanye Online Calon Legislatif Partai palitik Peserta Pemilu 2014. J. Ilmu Komun., Vol. 13. pp. 234-248 (2015)

[7] Eriyanto. : Analisis Framing: Konstruksi, Ideologi, dan Politik Media. (Yogyakarta: LkiS Group) (2011)

[8] Muhtadi, B. : Dilema PKS Suara dan Syariah. (Jakarta: Gramedia) (2012)

[9] Hasan, N. : Islam Politik di Dunia Kontemporer; Konsep, Genealogi dan Teori. (Yogyakarta: SUKA Press) (2012) 